\title{
Study on inter-personal violence among school going adolescents in a rural block of West Bengal
}

\author{
Chitra Chatterjee ${ }^{1}$, Shubhadeep Paul ${ }^{2}$, Gandhari Basu ${ }^{3}$, Anindya Mukherjee ${ }^{4}$ \\ ${ }^{1,3}$ (Community Medicine, College of medicine \& JNM Hospital, Kalyani, India) \\ 2 (Community Medicine, Malda Medical College \& Hospital, Malda, India) \\ 4(Community Medicine, Calcutta Medical College \& Hospital, India)
}

\begin{abstract}
The study was aimed to find out risk behavior related to interpersonal violence and demographic correlates among school going adolescents in a rural block of West Bengal. It was a cross sectional study conducted at a co-educational high school at Tarakeshwar block under service area of Medical College Kolkata. Overall 174 adolescents studying in class IX to class XII participated in the study. Proportions, Chi square test and Multivariate logistic regression were highlighted in statistical analysis. Twelve percent of study population thought of killing somebody, $23 \%$ males and 50\% females thought of hitting somebody in past 12 months, $12.6 \%$ carried weapon in past 30 days, $6 \%$ of study population injured somebody, $16 \%$ involved in physical fight inside school, 30.4\% repented after physical fight. Risk behavior increased with age and in nuclear families $(p<0.05)$, females were more violent in thinking domain. Findings were nearly similar to those in other countries. Large scale studies can be further informative.
\end{abstract}

Key Words: Adolescents, interpersonal violence, risk-behavior, WHO, weapon

\section{Introduction:}

Adolescence is defined by WHO as the age group of 10-19 years. In India, adolescents constitute $21.4 \%$ of the population. Adolescents empowered with appropriate life skills have a better chance of becoming healthy, responsible and productive adults. ${ }^{1}$ Without adequate regulation and monitoring, children tend to be impulsive, prone to risk taking, more susceptible to peer influences and more prone to health risk behaviors. ${ }^{2}$ For adolescents, school is an important setting outside the family. ${ }^{3}$ Supports from fellow students in school is related to lower subjective health complaints, satisfaction with school, and increased physical activity.Dissatisfaction with life and bullying by fellow friends may lead to self inflicted violence like suicide, interpersonal violence like involvement in physical fight etc ${ }^{4}$. In a large school based international study of adolescents in developed countries, violence related behavior were consistent and nearly similar ${ }^{4}$. The present study was carried out with the objective of finding out risk behavior related to interpersonal violence and demographic correlates among school going adolescents in a rural area and aimed to find out the association, if any, of health risk behaviors with various socio demographic attributes.

\section{Materials And Methods:}

It was an observational descriptive study with cross sectional study design conducted during $1^{\text {st } J a n u a r y ~}$ to $31^{\text {st }}$ March 2010 where study population were adolescents studying in class IX to XII in one co-educational high school; Hooghly district was randomly selected from 19 districts of West Bengal; subsequently Tarakeshwar block was randomly selected from blocks of Hooghly district. All the 10co-educational higher secondary schools in the block were identified and then by random selection the school under study was taken up. All the students in the selected classes, present on the day of the survey, were included in the study maintaining anonymity and voluntary nature of participation after obtaining consent from school authorities and guardians' committee and participants. Final sample size was 174 students of class IX to XII with response rate of 77.6\%. A self-administered questionnaire was used which was obtained after due modification from the study conducted by Rahul Sharma et $\mathrm{al}^{5}$ and was translated to local language with the help of subject specialists andwas pretested in another randomly selected higher secondary school in the same block. Then the pretested questionnaire was explained to the students taken up for actual study. The data thus collected wereput into Microsoft excel 2007. Adolescents were identified being 'at risk', if he or she answered in the affirmative to any of the individual risk behaviors comprising the particular domain.

Domain I: if any of the following risk behavior was positive then domain I was considered as positive.

a) Thinking of hitting someone in past $1 \mathrm{yr}$

b) Thinking of killing someone in past $1 \mathrm{yr}$

c) Carrying weapon in past 1 month (thinking of hitting someone with it)

Domain II: if any ofthe followingrisk behavior was positive then domain II was considered as positive. 
a) Threatened someone in past $1 \mathrm{yr}$

b) Injured someone in past $1 \mathrm{yr}$

c) Physical fight inside school with somebody in past $1 \mathrm{yr}$

d) Physical fight with somebody outside school in past 1 yr

For studying association, adolescents who responded "Yes" to any of the 3 individual questions of domain 1 was considered "at risk" and similarly those who responded "yes" to any of the 4 individual questions of domain 2 were considered "at risk". The association of risk behaviors with demographic factors of the adolescents was analyzed by applying Chi-square test with $95 \%$ confidence interval. Multivariate logistic regression was applied to analyze the relationship between risk behaviors and independent variables under study. Statistical software used was SPSS version 16.0.

\section{Results:}

Mean age of the study population was 16.66 yrs with standard deviation 0.83 years $(95 \% \mathrm{CI}=15$ to 18.32 years). Majorities were males $(74.70 \%)$ and all were Hindus with Bengali as mother tongue. Around $14.94 \%$ of study population earned money $(\mathrm{n}=26)$. Among money earners majority $(46.15 \%)$ earned < Rs 100 per month; $38.46 \%$ among the earners contributed to their respective families. Ten (5.7\%) students had no close friends, whereas $82(47.13 \%)$ students had $1-3$ close friends and another $82(47.13 \%)$ had 4 or more close friends.

Prevalence of risk behavior (both domain I and II) among male and female students was found as follows - carrying a weapon in past 30 days, threatening to injure or kill somebody with weapon in past 12 months, involvement in physical fight in past 12 months inside/ outside the school, injuring self or others in physical fight in past 12 months and repenting as a result of involvement in physical fight; females were significantly morelikely to think of hitting somebody in past 12 months than male (table 1).

The risk of thinking to be indulged in interpersonal violence among the respondents was significantly higher in those having some income belonging to nuclear families; the risk of actual indulgence in such violence was significantly higher in those having any income source, belonging to nuclear families or having more than 1 close friend (table 2).

Multinomial logistic regression was done with consideration of positive response to any of the questions in domain I and domain IIseparately as dependent variables and sex, type of family, earning of money and presence of close friends as independent variables; it was found that both the domains were significantly related to type of family, earning of money and presence/absence of close friends;sex was not significantly associated with positive response in any of the domains (table-3).

\section{Discussion:}

Rahul Sharma et $\mathrm{al}^{5}$ found that risk behavior increased in the lower ageswhich did not corroborate with the findings of the present study. This study showed that boys were more violent in action domain corroborating with that of Rahul Sharma et $\mathrm{al}^{5}$ and other international studies ${ }^{6}$.Risk factors in domain I and II were significantly higher among residents of nuclear family ( $45.2 \%$ and $40.8 \%$ respectively) as compared to joint families $(24.4 \%$ and $17.8 \%$ respectively)(Table 2$)$ probably due to more stresses possibly prevalent in family environment that were not addressed upon. Students with income had higher risk in both domain I and II as compared to non-earners ( $76.9 \%$ vs. $27 \%$ in domain I and $53.8 \%$ vs. $24.3 \%$ in domain II). This might be due to increased access to weapons or workplace disputes like findings of Rahul Sharma et $\mathrm{al}^{5}$. It is found that more females (50\%) thought of hitting somebody with/without weapon in past 1 year in comparison to males $(23.1 \%)$ and was similar for thinking of killing somebody in past year to seek revenge (female $13.6 \%$ vs. male 10.8\%).Present study showed that $12.3 \%$ males and $13.6 \%$ females carried a weapon in past 30 days. Girls mostly carried sticks, canes and scissors while knives, razor blades and sickles were carried mostly by their male counterparts. The causes were self esteem/pride, protection from animals and protection from other human beings if assaulted upon. Kishore et al. ${ }^{6}$ found that $12.5 \%$ of urban male adolescents carried a weapon in the past 30 days; Smith-Khuri et al. ${ }^{4}$ who found that an average of 10.7\% students aged 11-16 years in five countries reported having carried a weapon in past 30 days and Rahul Sharma et $\mathrm{al}^{5}$ found that $15.7 \%$ males (58/369) and 3.9\% females (3/181) carried a weapon in past 30 days. The findings of this study were almost similar to the above mentioned studies. Present study found that $6.15 \%$ males and $13.63 \%$ females threatened to injure others in past 12 months while $6.15 \%$ males and $4.5 \%$ females actually injured others while Rahul Sharma et $\mathrm{al}^{5}$ showed that $17.3 \%$ of males and $5.5 \%$ of females threatened or injured someone last year. This study showed that $13.8 \%$ males and $13.6 \%$ females were involved in physical fights outside school whereas $18.46 \%$ males and $9 \%$ females fought inside school whereas Rahul Sharma et $\mathrm{al}^{5}$ found that $49.1 \%$ males and $20.4 \%$ females were involved in physical fight in last year(without discriminating outside/inside of school) . Across the globe about $33 \%$ to $50 \%$ of adolescents report involvement in physical fights ${ }^{7-9}$ which was higher than those found in present study.Boys had higher rates of involvement in interpersonal violence ${ }^{10}$ - a similar 
finding observed in present study. It was found that adolescents having no close friends refrained from violence, similar to the findings of Rahul Sharma et $\mathrm{al}^{5}$. Having a bigger social network and interaction with larger number of peers can increase the chance of small disagreements or points of dispute.

\section{Conclusion:}

Cross sectional nature of the study prevented arrival at causal association. Moreover, the findings were restricted to school going adolescents only and that to a single co-ed school due to resource crunch. Recall bias might have also happened. Adolescents across different countries including India are similar in nature and proneness to risk behaviors concerned with interpersonal violence. School and college based large- scale studies along with coverage for school drop outs can be undertaken. Focused group discussions can be used for in-depth analysis of the reasons for violent behaviors.

\section{References:}

[1] World Health Organization. Adolescent peer education in formal and non-formal settings. Report of an inter-country workshop, Monastir, Tunisia 6- 9 December 2004. World Health Organization Regional Office for the Eastern Mediterranean Cairo 2005. Available at URL: http://www.who.int/WHO-EM/WRH/042/E 03.05/500.pdf (Accessed on: 22.10.2012)

[2] Barber BK. Adolescent socialization in context - the role of connection, regulation, and autonomy in the family. Journ. of Adol.Res.1997; 12:5-11.

[3] Currie C, Hurrelmann K, Settertobulte W, Smith R, Todd J. Health and Health Behaviour among Young People- Health Behaviour in School-Aged Children: A WHO Cross-National Study International Report. Copenhagen, Denmark: WHO Regional Office for Europe, 2000.

[4] Smith-Khuri E, Iachan R, Scheidt PC, Overpeck MD, Gabhainn SN, Pickett W, et al. A cross-national study of violence-related behaviours in adolescents. Arch Pediatr Adolesc Med. 2004; 158:539-44.

[5] Sharma R, Grover V L, Chaturvedi S.Risk Behavior related to interpersonal violence among school and college going adolescents in south Delhi. IJCM, Apr 2008;33 (2):85-88.

[6] Kishore J, Singh A, Grewal I, Singh SR, Roy K. Risk behaviour in an urban and a rural male adolescent population. Natl Med J India. 1999; 12:107-10.

[7] Vanderschmidt HF, Lang JM, Knight-Williams V, Vandeschmidt GF. Risks among inner-city young teens: the prevalence of sexual activity, violence, drugs and smoking. J Adolesc Health. 1993; 14:282-8.

[8] Miguel-Baquilod M. Global school-based student health survey (GSHS) in the Philippines. 2003-2004. Available from: http://www.cdc.gov/gshs/countries/philippines/Report-03.pdf. [Accessed on18.10.2012]

[9] Ruangkanchanasetr S, Plitponkarnpim A, Hetrakul P, Kongsakon R. Youth risk behavior survey: Bangkok, Thailand. J Adolesc Health. 2005; 36:227-35.

[10] Orpinas PK, Basen-Engquist K, Grunbaum JA, Parcel GS. The co-morbidity of violence-related behaviors with health-risk behaviors in a population of high school students. J Adolesc Health. 1995; 16:216-25.

Table1: Prevalence of risk behavior related with interpersonal violence among the respondents. $(\mathbf{n = 1 7 4 )}$

\begin{tabular}{|c|c|c|c|c|}
\hline Risk behavior & $\begin{array}{l}\text { Males }(\mathrm{n}=130) \\
\mathrm{N}(\%)\end{array}$ & $\begin{array}{l}\text { Females }(\mathrm{n}=44) \\
\mathrm{N}(\%)\end{array}$ & $\begin{array}{l}\text { Total }(\mathrm{n}=174) \\
\mathrm{N}(\%)\end{array}$ & Chi square, $p$ \\
\hline Think of hitting somebody in past 12 months & $30(23.1)$ & $22(50)$ & $52(29.9)$ & $\begin{array}{c}5.686 \\
0.017\end{array}$ \\
\hline Think of killing somebody in past 12 months & $14(10.8)$ & $6(13.6)$ & $20(11.5)$ & $0.133,0.716$ \\
\hline Carried a weapon in past 30 days & $16(12.3)$ & $6(13.6)$ & $22(12.6)$ & $0.026,0.871$ \\
\hline $\begin{array}{l}\text { Threatened or injured someone with a weapon } \\
\text { any time in past } 12 \text { months }\end{array}$ & $8(6.1)$ & $6(13.6)$ & $14(8.0)$ & $1.244,0.265$ \\
\hline $\begin{array}{l}\text { Physical fight inside school with somebody in } \\
\text { past } 1 \mathrm{yr}\end{array}$ & $24(18.5)$ & $4(9.0)$ & $28(16.1)$ & $1.069,0.301$ \\
\hline $\begin{array}{l}\text { Physical fight outside school with somebody in } \\
\text { past } 1 \text { yr }\end{array}$ & $18(13.8)$ & $6(13.6)$ & $24(13.8)$ & $0.001,0.98$ \\
\hline
\end{tabular}


Table 2: Association of risk behavior with interpersonal violence related to various demographic variables

\begin{tabular}{|c|c|c|c|c|c|}
\hline $\begin{array}{r}\text { Study charact } \\
\text { res }\end{array}$ & $\begin{array}{l}\text { ics (number of } \\
\text { ents) }\end{array}$ & \multirow[t]{2}{*}{$\begin{array}{l}\text { Number of } \\
\text { respondents } \\
\text { having risk } \\
\text { behavior }(\%) \\
\text { according to } \\
\text { domain } 1 \\
4(40)\end{array}$} & $\begin{array}{c}\text { Chi square, } p \\
\text { value }\end{array}$ & \multirow[t]{2}{*}{$\begin{array}{l}\text { Number of } \\
\text { respondents } \\
\text { having risk } \\
\text { behavior }(\%) \\
\text { according to } \\
\text { domain } 2\end{array}$} & Chi square,$p$ value \\
\hline Age in years & $15(10)$ & & $8.004,0.091$ & & $4.376,0.358$ \\
\hline & $16(68)$ & $14(20.6)$ & & $16(23.5)$ & \\
\hline & $17(70)$ & $26(37.1)$ & & $24(34.3)$ & \\
\hline & $18(24)$ & $14(58.3)$ & & $10(41.7)$ & \\
\hline & $19(2)$ & $2(100)$ & & 0 & \\
\hline \multirow[t]{2}{*}{ Gender } & Male (130) & $38(29.2)$ & $3.138,0.076$ & $38(29.2)$ & $0.031,0.861$ \\
\hline & Female (44) & $22(50)$ & & $12(27.3)$ & \\
\hline \multirow{2}{*}{$\begin{array}{l}\text { Respondents } \\
\text { working for } \\
\text { income }\end{array}$} & Yes (26) & $20(76.9)$ & $12.185,0.000$ & $14(53.8)$ & $4.706,0.030$ \\
\hline & No (148) & $40(27)$ & & $36(24.3)$ & \\
\hline \multirow{2}{*}{$\begin{array}{l}\text { Type of } \\
\text { family }\end{array}$} & Nuclear (84) & $38(45.2)$ & $4.158,0.041$ & $34(40.8)$ & $5.466,0.019$ \\
\hline & Joint (90) & $22(24.4)$ & & $16(17.8)$ & \\
\hline \multirow{3}{*}{$\begin{array}{l}\text { Number of } \\
\text { close friends }\end{array}$} & None (10) & 0 & $3.656,0.161$ & 0 & $6.963,0.031$ \\
\hline & $1-3(82)$ & $34(41.5)$ & & $34(41.5)$ & \\
\hline & $\geq 4(82)$ & $26(31.7)$ & & $16(19.5)$ & \\
\hline
\end{tabular}

Table 3: Multinomial logistic regression with domain 1 and domain 2 as dependent variables and sex, type of family, housing, earning money, presence of close friends as independent variables

\begin{tabular}{|c|c|c|c|}
\hline \multicolumn{2}{|c|}{ Domain $1(\mathrm{p}=0.709)$} & \multirow{2}{*}{$\begin{array}{l}\text { Slope } \\
-1.173\end{array}$} & \multirow{2}{*}{$\begin{array}{c}\text { Significance } \\
0.060\end{array}$} \\
\hline Sex & Male & & \\
\hline \multirow{3}{*}{$\begin{array}{l}\text { Type of } \\
\text { family }\end{array}$} & Female (S) & & \\
\hline & Nuclear & 1.185 & 0.032 \\
\hline & Joint(S) & & \\
\hline \multirow[t]{2}{*}{ Housing } & Pukka & -0.603 & 0.304 \\
\hline & Others(S) & & \\
\hline \multirow{2}{*}{$\begin{array}{l}\text { Money } \\
\text { earning }\end{array}$} & Yes & 2.908 & 0.001 \\
\hline & No(S) & & \\
\hline \multirow{2}{*}{$\begin{array}{l}\text { Number of } \\
\text { close friends }\end{array}$} & None & -20.962 & 0.000 \\
\hline & 1 or more $(\mathrm{S})$ & & \\
\hline \multicolumn{2}{|c|}{ Domain $2(\mathrm{p}=0.032)$} & & Significance \\
\hline \multirow[t]{2}{*}{ Sex } & Male & 0.278 & 0.664 \\
\hline & Female(S) & & \\
\hline \multirow{2}{*}{$\begin{array}{l}\text { Type of } \\
\text { family }\end{array}$} & Nuclear & 1.338 & 0.014 \\
\hline & Joint(S) & & \\
\hline \multirow[t]{2}{*}{ Housing } & Pukka & -0.535 & 0.343 \\
\hline & Others(S) & & \\
\hline \multirow{2}{*}{$\begin{array}{l}\text { Money } \\
\text { earning }\end{array}$} & Yes & 1.655 & 0.021 \\
\hline & $\mathrm{No}(\mathrm{S})$ & & \\
\hline \multirow{2}{*}{$\begin{array}{l}\text { Number of } \\
\text { close friends }\end{array}$} & None & -20.048 & 0.000 \\
\hline & 1 or more $(\mathrm{S})$ & & \\
\hline
\end{tabular}

